\title{
ASSESSING STRUCTURE IN AMERICAN ONLINE PURCHASE OF TRAVEL PRODUCTS
}

\begin{abstract}
The Internet has become the primary channel for the purchase of a number of travel-related products including airline tickets, hotel reservations, car rental, tickets to events and attractions, etc. This study examines the pattern of travel-related products purchased online by American travelers. The results of this study indicate that there is a strong hierarchical structure in the purchasing of eight travel-related products. Also, it appears that American travelers can be roughly classified into three travel product groups ranging from the 'Core Internet Traveler' and 'Advanced Internet Traveler' to the 'Comprehensive Internet (or Complete) Traveler.' Finally, an analysis of the travelers indicates that they differ significantly in terms of demographic characteristics, information search behavior, and travel planning activities. These findings offer a number of important implications for destination marketing.
\end{abstract}

KEYWORDS: Online purchase, travel and hospitality products, destination marketing, Guttman Scalogram Analysis 


\section{Assessing Hierarchical Structure in American Online Purchase of Travel Products}

\section{INTRODUCTION}

The Internet has reshaped many facets of travel including information search and planning (Mills \& Law, 2004; Xiang, Wöber, \& Fesenmaier, 2008) as well as the purchase of travel-related products (Buhalis \& Law, 2008; Werthner \& Klein, 1999). Indeed, studies conducted by the Pew Foundation Internet Project (2009) indicate that travel reservations are one of the most popular online activities for American travelers, and that the percent of U.S. adults who booked or purchased travel products increased by about $250 \%$ between 2000 and 2009 . Also, a 2009 report by USTA (2009) indicates that $96.8 \%$ of online American travelers use the Internet for travel planning (or online travelers), and $80.3 \%$ of online American travelers purchase travel products for pleasure trip purposes.

Several researchers have sought to identify the factors that affect traveler's Internet purchasing behaviors; these include personal factors (Internet skill, experience, and innovativeness) (Jun, Vogt, \& MacKay, 2007; Lee, Qu, \& Kim, 2007; Yang \& Lester, 2004), technology design factors (information, system, and service quality) (Lee \& Lin, 2005; Park \& Kim, 2003; Wen, 2009), and context factors (travel purposes and travel party) (Fodness \& Murray, 1999; Pennington-Gray \& Vogt, 2003). They have also identified important differences between those that have purchased tourism products online and those who have not (Chu, 2001; Kim \& Kim, 2004; Law \& Leung, 2000; Susskind, Bonn, \& Dev, 2003). This research indicates that most American travelers who use the Internet for travel planning also use the Internet to purchase products. Importantly, most of this research has focused attention on the purchase of a single travel product such as an airline ticket or hotel reservation. However, the USTA (2009) report indicates that few people purchase online only one travel product. As such, it seems that it 
is unnecessary to differentiate between 'Lookers' - those travelers who use the Internet to search information, but not to purchase products, and 'Bookers' - those travelers who use the Internet to purchase products as well as search for travel information (Carroll, Kwortnick, \& Rose, 2007; Kim, Bojanic, \& Warnick, 2009; Tanford, Baloglu, \& Erdem, 2011). Werthner and Ricci (2004) and Jeng and Fesenmaier (2002), among others, argue that the tourism product itself is a bundle of basic products, and that travelers tend to purchase these bundles due to convenience (Naylor \& Frank, 2001) and low price (Sheldon \& Mak, 1987). However, there are few studies that have examined the range and pattern of travel products purchased online. Therefore, the primary goal of this study is to identify the structure of the online purchasing patterns of American travelers across a range of travel-related products. An important second goal is to identify differences (i.e., in terms of demographic characteristics, travel planning patterns, and internet use including online information search) between American travelers with different online purchasing behaviors. The theoretical background is briefly discussed in next section, followed by a third section which discusses the methodology used to address the goals of the study. The fourth section of the paper presents the findings and the implications are discussed in the final section of this paper.

\section{BACKGROUND}

The Internet is one of the most important sources for travel information in that it enables travelers to easily collect information about travel products whenever, wherever, and as much as they want (Hwang, Gretzel, Xiang, \& Fesenmaier, 2006; O’Connor, 1999; Pan \& Fesenmaier, 2006); additionally, the Internet has empowered travelers to purchase an array of travel products by bypassing traditional intermediaries in the distribution channel (Beldona, Nusair, \& Demicco, 
2009; Kumar, Lamg, \& Peng, 2004; Lang, 2000; Werthner \& Klein, 1999). Thus, online travel companies such as Expedia.com, Kayak.com, Lastminute.com, Orbitz.com, and Travelocity.com enable travelers to easily check price, search for up-to-date information, purchase last-minute or online specials, and communicate directly with sellers and/or other consumers (Jang, 2004; Law \& Leung, 2000).

Several studies have investigated online travel product purchasing behavior wherein they have examined the nature and extent of purchase of certain travel products (e.g., airline tickets, hotel bookings, cruise purchasing and so on) (Chu, 2001; Kim \& Kim, 2004; Morrison, Jing, O'Leary, \& Cai, 2001). The results of these studies indicate that airline tickets are the most popular travel product followed by accommodations, with travel packages the least popular (Card, Chen, \& Cole, 2003; Mast, Shim, \& Morgan, 1991). Another study by Morrison et al. (2001) showed similar results for airline tickets whereby they (airline tickets) are the most popular online product purchased followed by accommodations. Numerous studies have investigated the differences between consumers who prefer to use the Internet purchase products (i.e., Bookers) and those who do not (i.e., Lookers); the results indicate that online consumers tend to have higher levels of the Internet use, skills and innovation than typical consumers (Ahuja, Gupta, \& Raman, 2003; Monsuwé, Dellarert, \& Ruyter, 2004; Zhou, Dai, \& Zhang, 2007). In tourism, Kah, Vogt, and MacKay (2008) found that high innovators (i.e., Internet adoption) and more frequent users of the Internet are more likely to purchase a range of travel products (Christou, Avidimiotis, Kassianidis, \& Sigala, 2004; Lee et al., 2007). Jun et al. (2007) compared different types of travel products travelers purchased and information sources they used (e.g., online, offline and both online and offline). They concluded that accommodations, car rentals and flights are leading travel products that travelers are more likely to search information 
for and purchase via the Internet.

Additional travel studies have attempted to explain the online purchasing behavior based on different levels of product complexity (Anckar \& Walden, 2002; Beldona, Morrison, \& O'Leary, 2005; Nysveen, 2003). These studies indicate that flights, hotels (or lodging/accommodations), and rental cars are standardized and transactional service products such that travelers do not need much information and thus, consider them as "low-risk" products. In contrast, complex travel products such as travel packages, cruises, and RV (Recreation Vehicle) rental require a substantially higher level of information and interactivity between sellers and buyers before purchase (Card et al., 2003; Anckar \& Walden, 2002; Morrison et al., 2001; Susskind et al., 2003). These studies suggest that travelers feel more comfortable, and therefore are more likely to purchase online, low-risk products such as airline tickets and hotel reservations. However, as travelers become more skilled and trusting of Internet purchases, they “add" high-risk products, including travel packages (Anckar \& Walden, 2002; Mitchell, 1999; Jun et al., 2007; Nysveen, 2003). Following from this literature, it is argued in this study that while some travelers purchase only what might be referred to as "low risk travel products" (e.g., airline tickets or hotel reservations), other travelers may use the Internet to purchase a range of travel products, effectively bundling both low-risk and high-risk products. With this proposition in mind, the goal of this study is to identify the extent to which American travelers purchase travel-related products online; an additional goal is to identify various factors which differentiate travelers that purchase only low risk products from those that tend to bundle other types of travel products.

\section{METHODOLOGY}


A national survey of Americans who had travelled and used the Internet during calendar year 2009 was conducted in January $5^{\text {th }}-15^{\text {th }} 2010$. Overall, 10,000 members of an online panel of Americans maintained by Survey Sampling International (SSI) were invited to participate in the survey. A total of 3,982 adults (persons 18 years or older) responded to the Internet use and travel-related questions. Of these persons, $73.5 \%(2,926)$ indicated they had taken a trip during the previous 12 months which was 50 miles or more, one-way from home or included an overnight stay; 2,137 of these responses were retained as complete. The sample of completed surveys was weighted using U.S. Census data based upon three aspects of the population (i.e., age, race and gender) that have been shown to significantly affect Internet use in order to represent the U.S. online population of adults ages 18 or over (Pew Foundation, 2009). This post-stratification weighting approach enables researchers to rebalance the distribution of responses within the sample so that it corresponds (in terms of these variables) more closely to the overall population thereby reducing bias within the overall study (Lessler \& Kalsbeek, 1992; Park \& Fesenmaier, in-press).

The questionnaire was organized into three sections and included a number of questions related to online travel purchases during calendar year 2009. The first section asked a series of general questions regarding Internet usage including frequency of use, Internet knowledge, technology equipment people own, perceived technology innovativeness, and perceived information overload (Pan \& Fesenmaier, 2006). The next set of questions was related to travel behaviors including the number of travel experiences, online purchasing of eight travel products, and online information sources used to obtain information during the previous year (2009). More specifically, respondents were asked to select all of travel products or service that they have purchased or reserved online for trips in the past 12 months. The third part of the survey asked 
questions about demographics of the respondent including age, gender, income and family status.

Data analysis followed a three step process in order to address the research goals of the study. First, frequency analysis was conducted to identify the popularity of purchase of the following eight travel-related products during calendar year 2009: 1) airline tickets, 2) lodging accommodations, 3) car rental, 4) travel packages, 5) cruise reservations, 6) reservations to attend sporting activities (e.g., golf, skiing, or water sports), 7) purchase and/or reservations for recreational vehicle rentals, and 8) admission tickets to a theme/amusement park, play, show or concert, museum, festival or other event, or a tour or excursion. Guttman scaling using Scalogram Analysis was then used to examine the cumulative structure of online travel product purchasing, where travel products and respondents can be scaled at the same time based upon a ‘scalability matrix' (Ekinici \& Riley, 1999; McIver \& Carmines, 1981). The scalability of the response patterns were evaluated first based upon the Coefficient of Reproducibility (CR), which involves estimating the scale error using the Goodenough-Edwards error assessment (Fesenmaier, Vogt, \& Stewart, 1993; Guttman, 1950; McIver \& Carmines, 1981; Roehl, 1990). The CR is a measure of the relative degree to which the observed scale is consistent with perfect scale. It is estimated by counting up the number of responses that have been shown incorrectly for each person on the basis of his/her scale score (referring to error), and dividing these errors by the total number of responses and subtracting the error scale from one (Gutman, 1950). The formula for CR can be expressed as follows:

$$
\begin{gathered}
C R=1.0-\frac{\# \text { of errors }}{\text { Total responses }} \\
=1.0-\frac{\# \text { of errors }}{(\# \text { of items }) \times(\# \text { of respondents })}
\end{gathered}
$$


Guttman (1950) suggests a standard of $10 \%$ errors, so a CR over 0.90 is acceptable. Although the Goodenough-Edwards CR protects against the possibility of a spuriously high level of reproducibility due to its error counting procedure conducted by observed responses rather than inferred responses, items with extreme marginal distributions tend to inflate the value of CR. As a precaution against this possibility, Edwards (1957) recommends comparing CR to the Minimum Marginal Reproducibility (MMR). The MMR can be calculated as follows:

$$
M M R=\frac{\text { Total responses }- \text { marginal errors }}{\text { Total responses }}
$$

Menzel (1953) also argues that the CR is not robust enough to accurately measure scalability because the value varies depending on the marginal distribution of category; he proposed the Coefficient of Scaleability (CS) as defined by the following formula:

$$
\begin{gathered}
C S=1-\frac{\# \text { of errors }}{\text { Maximum errors }(M E)} \\
M E=I N-\sum_{\text {Individual } 1}^{\text {Individual } N} \text { Smax }
\end{gathered}
$$

Where $\mathrm{I}=$ number of items; $\mathrm{N}=$ number of individuals; $\mathrm{Smax}=$ sub-score (frequency of responses) for the modal category of an individual.

The requirements of CS include: (1) CS should be lower than .90 and CR, except where they both equal to '1'; and, (2) CS should be somewhere between .60 and .80 to be accepted (Stouffer et al., 1950).

The third phase of the study used the results of the Scalogram analysis as a basis to 
classify the American travelers according to their online purchase patterns. As part of this analysis, Chi-square analysis and ANOVA were used to test for differences in travel, Internet experience, and information search behavior among the respective groups.

\section{RESULTS}

The results of this survey indicate that $75.3 \%(n=1,610)$ of the American online travelers surveyed $(\mathrm{N}=2,137)$ purchased at least one travel product via the Internet during the previous year (2009). An analysis was conducted to compare online American travelers (overall sample) to those who have not purchased travel products online (i.e., e-lookers) and those who have purchased travel products online (i.e., e-bookers). As can be seen in Table 1, the demographic characteristics of the entire sample of online American travelers and e-bookers are very similar (with no tests exceeding $\alpha=0.05$ ). Within American travelers purchasing travel products, females $(51.4 \%)$ were slightly more prevalent than males $(48.6 \%)$ and the ages of these respondents was evenly distributed (ages $18-21=9.4 \%$, ages $22-29=15.7 \%$, ages $30-39=$ $21.3 \%$, ages $40-49=20.7 \%$, ages $50-59=12.9 \%$, ages $60-69=8.9 \%$, and ages 70 and above $=11.1 \%$ ). Also, most American travelers have an annual income between $\$ 50,000$ and $\$ 149,999$ and are highly educated, having some college education or higher. Finally, more than half of American travelers are married and are employed either full or part-time.

Statistical comparisons between e-lookers and e-bookers indicate that they are quite different, except for gender. Specifically, online travelers who have not purchased travel products are significantly older (over 50 years $=42.2 \%$ ), have a lower annual income (Less than 39,999= 41.5\%), lower education level (less than high school and complete high school $=21.0 \%$ ), more single or never married $(22.7 \%)$ and not employed $(24.4 \%)$ than those who have purchased 
products online.

Insert Table 1 here

Table 2 presents the frequencies of the travel products purchased online by American travelers during calendar year 2009. The results indicate that most online American travelers surveyed made reservations for lodging accommodations (67.4\%) and purchased airline tickets (65.1\%), followed by event/attraction tickets (37.3\%) and car rental (34.9\%), which are substantially less popular online travel products. This contrasts to the very few travelers who used the Internet to rent recreational vehicles (2.0\%), reserve sporting activities $(6.1 \%)$, purchase reservations for a cruise $(10.1 \%)$ or purchase travel packages $(11.4 \%)$. These findings are consistent with previous research indicating that airline tickets and lodging reservations are the two most popular travel products purchased online, and very few people purchase travel packages and/or cruises via the Internet (Morrison et al., 2001).

\section{Insert Table 2 here}

The next phase of the study focused on assessing the overall structure or pattern of online purchasing based on the number of products travelers purchased online. This analysis is based upon the notion that there is a strong hierarchical or cumulative pattern among the travel products. That is, it is hypothesized that airline and hotel reservations would be the "first" product to be purchased online, while other travel products that require more information (i.e., travel packages and cruise reservations, etc.) would be purchased only by those travelers that have purchased the 'less risky' travel products. The results of this analysis indicate that, on 
average, online American travelers purchased 2.4 travel products via the Internet during 2009; of these travelers, 32.1 percent purchased only one product and an additional 48.8 percent purchased 2 - 3 products, while 17.0 percent of the online travelers purchased $4-5$ products, and 2.1 percent purchased 6 or more travel-related products (see Table 3 ). These findings indicate that approximately a third $(32.1 \%)$ of American online travelers buy a single travel product online, while over two thirds of American online travelers purchase two or more travel products online.

Insert Table 3 here

Multiple response analysis was conducted to construct a scalogram based upon the number of travel products purchased online. As can be seen in Figure 1 and Table 4, 45 percent of the online travelers that purchased one item (516 respondents) made a lodging reservation while another 43 percent purchased airline tickets; thus, only 12 percent of the respondents purchased a travel product other than airline tickets or overnight accommodations. Among travelers that purchased two items (443 respondents), the percentages of airfare and/or lodging purchases increased to about 65 percent (i.e., 68\% for lodging and 60\% for airline tickets). Furthermore, the percentage of travelers purchasing event/attraction admission tickets and making rental car reservations increased substantially to 34 percent and 21 percent, respectively. For the 343 travelers purchasing three items, the purchase of lodging reservations and airline tickets increased to about 85 percent, attraction/event tickets and rental car reservations appear to become "additional" or extended travel products as they are purchased by 48 percent and 59 percent of online travelers. Interestingly, the 78 travelers purchasing five products add travel packages $(49 \%)$ to the four travel products listed above, while substantially fewer travelers use 
the Internet to reserve personal sporting activities (31\%) or to rent RVs (11\%). Last, for those few (34) travelers who purchased six or more travel products, reservations for a cruise and sporting activities were added to the list of travel products purchased online.

The cumulative structure of online purchasing was tested using Guttman analysis (Guttman, 1950). As the first step in this analysis, the amount of error was measured by computing the deviations of the observed response pattern from the ideal pattern (i.e., where there is a perfect cumulative pattern). In this study, the 'ideal pattern' exists when there is a monotonic increase in the percentage of purchases for each travel product, depending on the number of travel products purchased. For example, online purchases of lodging consistently increases from 45 percent (at 1 product purchased) to 100 percent when six travel products are purchased. This is largely true for all travel products. An additional condition for the ideal pattern' is that the percent of purchases of a product located above in the scalogram exceeds those located below; for example, the percentage of "single product" respondents purchasing lodging is 45 percent, while airline tickets is 43 percent, admission tickets and car rental are four percent, etc. (see Table 4); and the pattern is similar for those persons purchasing 2 travel products. However, cases are considered as errors when they do not follow this pattern. For example for those persons purchasing 3 travel products, the percent purchasing airline tickets is higher (85\%) than lodging (84\%) and car rental (59\%) exceeds admission tickets at 48 percent. Based on this approach in calculating errors, the CR value (0.88) is slightly lower than the minimum acceptable value (0.90) as suggested by Guttman (1950) and McIver and Carmines (1981). However, the values for MMR of 0.67 and CS (0.66) meet the requirements, indicating that the online purchase of travel products has a reasonably strong hierarchical/cumulative (i.e., Guttman) structure (see Table 4). 
Insert Table 4 and Figure 1 here

The pattern of online purchases seems to suggest differences in the nature of the travel products and the travelers themselves, and that the purchase patterns can be roughly categorized into three groups. More specifically, it is argued that one group includes those travelers that purchased one or two basic travel products - airline tickets and/or lodging reservations; this group of American travelers represents 59.6 percent of the respondents and may be described as "Core Internet Travelers" (CIT). The second group of travelers purchased three or four travelrelated products online, mostly airline tickets and lodging along with car rentals and event/attraction tickets, and are labeled "Advanced Internet Travelers" (AIT); this group accounts for 33.5 percent of online American travelers. Last, a third group of travelers are labeled 'Comprehensive Internet Travelers' as they purchased five or more travel products online including airline tickets, lodging, car rentals and event/attraction tickets, along with travel packages and cruise reservations, etc.; this group accounts for only $6.9 \%$ of online American travelers that purchased travel products online (see Figure 1).

Based upon this categorization, a final set of analyses was conducted to identify the differences among the three travel product groups in terms of demographics, travel and information search behaviors, as well as Internet use. The results of these analyses indicate that Comprehensive Internet Travelers are highly educated ('Complete college' $=35.5 \%$ and 'Post graduate' $=30.0 \%$ ), have a higher annual income (over $\$ 100,000=40.5 \%$ ) and are younger ('22 $\left.-39^{\prime}=40.5 \%\right)$ than those included in the Core Internet Traveler and Advanced Internet Traveler (see Table 5). Members of the Advanced Internet Traveler group, on the other hand, are more 
likely to be employed full-time $(49.6 \%)$ and more educated ('Complete college' $=31.0 \%$ and 'Post graduate' $=31.4 \%$ ) with a higher annual income (over $\$ 100,000=34.1 \%$ ) than the Core Internet Traveler ('Employed full time' $=40.4 \%$; 'Complete college' $=25.4 \%$ and 'Post graduate' $=19.5 \%$; over $\$ 100,000=17.9 \%$.

\section{Insert Table 5 here}

Table 6 summarizes the results of the analyses examining differences among the three groups in terms of travel planning involvement, including the number of trips in last 12 months and degree of Internet usage for trip planning and travel purchasing, between travel product groups. The results indicate that Comprehensive Internet Travelers (' 5 or more trips' $=42.5 \%$ and ' $3-4$ trips' $=34.0 \%$ ) have traveled significantly more than Advanced Internet Travelers ('5 or more trips' $=25.2 \%$ and ' $3-4$ trips' $=36.9 \%$ ) and Core Internet Travelers (' 5 or more trips' $=$ $17.0 \%$ and ' $3-4$ trips' $=29.6 \%$ ) in last 12 months. In terms of Internet usage for travel planning and purchasing products, Comprehensive Internet travelers use the Internet significantly more often for travel planning ('All or $100 \%$ ' $=33.0 \%$ and ' $75-99 \%$ ' $=42.9 \%$ ) and purchasing products ('All or $100 \%$ ' $=35.1 \%$ and ' $75-99 \%$ ' $=42.3 \%$ ) than Advanced Internet Travelers ('All or $100 \%$ ' $=35.4 \%$ and ' $75-99 \%$ ' $=32.1 \%$ for travel planning, and 'All or $100 \%$ ' $=38.6 \%$ and ' $75-99 \%$ ' $=34.4 \%$ for product purchasing) and Core Internet Travelers ('All or 100\%' = $28.5 \%$ and ' $75-99 \%$ ' $=29.6 \%$ for travel planning, and 'All or $100 \%$ ' $=35.3 \%$ and ' $75-99 \%$ ' $=$ $26.4 \%$ for product purchasing) (see Table 6).

Insert Table 6 here 
Analyses were also conducted to compare the travel product groups regarding information search activities (specifically, their usage of various travel-related websites), where one might assume that the Core Internet Traveler would use substantially fewer and different channels when planning their trip. As expected, the results of these analyses indicate that the Comprehensive Internet Travelers are significantly more likely to use all information sources possible (i.e., number and usage of online travel information sources) as compared to the Core Internet Travelers and Advanced Internet Travelers when planning their trips (see Table 7). Also as one might expect, Core Internet Traveler appears to limit their use of the Internet to those sites supporting the purchasing of airline tickets or hotel reservations such as online travel agencies (60.4\%) and company websites (51.9\%). This contrasts sharply with the Comprehensive Internet Travelers, where they are much more likely to use a wide array of online tools including online travel agencies, company sites, search engines, destination sites as well as general travel sites and travel guide book sites. Advanced Internet travelers lie somewhere in between whereby they appear to use online travel agencies $(75.1 \%)$, company websites $(74.2 \%)$, search engines $(55.5 \%)$ and destination sites (43.2\%).

\section{Insert Table 7 here}

A final series of analyses were conducted to evaluate possible differences in the travel product purchase groups in terms of their online skills, innovativeness, satisfaction and the likelihood to use the Internet for their future travel planning. In this analysis, it was hypothesized that that the Core Internet Traveler would be substantially less skilled and knowledgeable the Internet as compared to those travelers purchasing online many travel products. The results indicate that Comprehensive Internet Travelers have significantly $(\alpha=0.05)$ higher perceived 
knowledge $($ Mean $=4.11 p<.01)$, innovativeness $($ Mean $=3.41,3.40$, and 3.63, $p<.001)$, satisfaction $($ Mean $=4.61, p<.001)$, and intention to use for next travel planning $($ Mean $=5.62, p$ $<.001$ ) as compared to the other two groups (see Table 8). The Advanced Internet Traveler also has relatively higher mean values in Internet-related variables as compared to Core Internet Traveler $(p<.001)$.

Insert Table 8 here

\section{DISCUSSION}

The Internet has had a substantial impact on the purchase of travel products, and in particular airline and hotel reservations; however, a wide array of travel products are now sold online including car rental reservations, tickets to attractions and events, cruise reservations and tickets to sporting events. Most research in this area has focused on 'lookers' and 'bookers' within the context of a single travel product, thus ignoring the overall pattern of online purchases. This study argues that most American travelers purchase a number of travel-related products online and that these purchases follow a strong hierarchical pattern whereby some travelers purchase only airline or lodging reservations while other travelers purchase airline and lodging reservations as well as other travel-related products (i.e., car rental or travel packages). Further, it is hypothesized that there are some travelers that purchase online a wide range of travel-related products. Consistent with Morrison et al. (2001), the results of this study indicate that lodging reservations and airline tickets are by far the most frequently purchased items via the Internet; however, American travelers also purchase tickets for attraction/events, car rental reservations, travel packages, cruise reservations, tickets to sport activities, and RV rental and purchase. 
Scalogram analysis was employed based upon the number of products purchased in order to assess the cumulative structure or pattern of purchases. The results of this analysis (the reproducibility and scalability indexes are: $\mathrm{CR}=0.88, \mathrm{MMR}=0.67$, and $\mathrm{CS}=0.66$ ) indicate that there is a strong hierarchical structure in online purchasing of travel products. That is, lodging reservations and airline tickets are essentially the only travel-related products purchased online by those travelers that have purchased one travel-related product. In the case of two items purchased, most of online travelers bought either of these two products along with event tickets or car rental reservations. For travelers purchasing $3-5$ travel products, hotel reservations and airline tickets are purchased by virtually everyone while event tickets, car rental reservations, travel packages and cruise line reservations become extremely popular.

The pattern of online purchases seems to suggest differences in the nature of the travel products as well as the travelers such that they can be classified into three groups: Core Internet, Advanced Internet and Comprehensive Internet Travelers. In this study Comprehensive Internet Travelers $(6.9 \%)$ are those American travelers who purchased online five or more travel products; they are younger, have a significantly higher income, are much more likely to have full-time employment, more experienced in travel, they search a greater number of information sources when planning travel, and are more innovative and experienced with the Internet than travelers in the other groups. The Advanced Internet Travelers (33.5\%) are similar to Comprehensive Internet Travelers with respect to the various aspects used to assess the travel groups and differ substantially from travelers that comprise the Core Internet Travelers. Importantly, these results suggest that online travel-related products face some kind of "threshold" wherein travelers appear to become more comfortable (and more involved) with online travel planning (including purchasing travel products). That is, many travelers accomplish their buying decisions for "basic" 
and less complex products first, and then successively increase their use of the Internet for purchasing more complex products (Beldona et al., 2005). However, the results of these analyses also seem to suggest that the three travel product groups including the number of travel products purchased are fundamentally different in terms of their travel planning involvement, demographics, and Internet related variables. For example, Comprehensive Internet Travelers (those who purchased over five items) tend to not only be younger and have a higher income, but they have significantly more Internet experience, technology innovativeness, and as one might expect, are much more involved in travel planning than the Core Internet Travelers and Advanced Internet Travelers.

Several practical implications can be drawn for destination marketing organizations (DMOs) and online travel and hospitality businesses. First, it is posited that businesses promoting tourism products online need to consider the "cluster" of buying behaviors when developing travel related products. Since online travelers would be likely to purchase similar types of travel products in terms of the complexity degree and the function of the product, business marketers need to identify the "cluster" of purchasing behaviors of the traveler, and then provide a customized set of online travel products. In addition, destination marketers need to provide different types of tools to support the different purchasing groups as they differ substantially in terms of Internet knowledge, innovativeness, satisfaction, usage and the information sources they use.

There are two major limitations in this study. First, this study did not take two important travel-related factors into account that potentially affect online purchasing behaviors; these are travel risk perception (Money \& Crotts, 2003) and past purchasing behavior (Beldona et al., 2005; Morrison et al., 2001). Thus, future studies should examine the degree to which business 
travelers may be more likely to purchase airline tickets and/or hotel rooms while pleasure travelers might book airline and lodging accommodations as well as reserve rental car or tickets for attractions/events. This study should also consider the extent to which pleasure travelers purchase travel package product. In terms of frequency of product purchasing, it can be argued that as a traveler frequently purchase a certain type of travel product, he/she may be familiar to the product, and the perceived risk and uncertainty of the expected product quality will be diminished. Thereby, the traveler will be more easily to purchase the product via the Internet. Additionally, this study just focused on domestic travel; however, online purchasing behavior by international traveler may be substantially different. Thus, future studies should consider both international and domestic travel. With these limitations acknowledged, it is posited that the hierarchical online purchasing pattern found in this study provides a strong foundation for understanding the relationships of travel-related products. 


\section{REFERENCES}

Ahuja, M., Gupta, B., \& Raman. P. (2003). An empirical investigation of online consumer purchasing behavior. Communications of the ACM, 46(12), 145-151.

Anckar, B., \& Walden, P. (2002). Self-booking of high and low complexity travel products: Exploratory finding. Information Technology and Tourism, 4, 151-165.

Beldona, S., Morrison, A.M., \& O'Leary, J. (2005). Online shopping motivations and pleasure travel products: A correspondence analysis. Tourism Management, 26, 561-570.

Beldona, S., Nusair, K., \& Demicco, F. (2009). Online travel purchase behavior of generational cohorts: A longitudinal study. Journal of Hospitality Marketing and Management, 18, 406-420.

Buhalis, D., \& Law, R. (2008). Progress in information technology and tourism management: 20 years on and 10 years after the Internet - the state of etourism research. Tourism management, 29(4), 609-623.

Card, J., Chen, C., \& Cole, S. (2003). Online travel products shopping: Differences between shoppers and nonshoppers. Journal of Travel Research, 42(2), 133-139.

Carroll, W.J., Kwortnick, R.J., \& Rose, N.L. (2007). Travel packaging: An Internet frontier. Cornell Hospitality Reports, 17(7), 4-16.

Christou, E., Avidimiotis, S., Kassianidis, P., \& Sigala, M. (2004). Examining the factors influencing the adoption of web-based ticketing: Etix and its adopters. In: Frew, A.J. (Ed.), Information and Communication Technologies in Tourism. Vienna, Austria, Springer.

Chu, R. (2001). What online Hong Kong travelers look for on airline/travel websites? International Journal of Hospitality Management, 20, 95-100.

Edwards, A.L. (1957). Techniques of attitude scale construction. Appleton-Century-Crofts, New York.

Ekinici, Y., \& Riley, M. (1999). The application of the Guttman scaling procedure in the measurement of consumer behaviour: A marketing myopia. Journal of Travel and Tourism Marketing, 8(4), 25-42.

Fesenmaier, D.R., Vogt, C.A., \& Stewart, W.P. (1993). Investigating the influence of welcome center information on travel behavior. Journal of Travel Research, 31, 47-52.

Fodness, D., \& Murray, B. (1999). A model of tourist information search behavior. Journal of Travel Research, 37(3), 220-230.

Guttman, L.L., (1950). The basis of scalogram analysis. In: Stouffer, S.A., et al. (Eds.), Measurement and Prediction. Princeton University Press, Princeton, NJ.

Hwang, Y-H., Gretzel, U., Xiang, Z., \& Fesenmaier, D.R. (2006). Information search for travel decisions. In: Fesenmaier, D.R., Wöber, K., Werthner, H. (Ed.), Destination 
recommendation systems: Behavioural foundations and applications, CABI, Wallingford, UK (2006), pp. 3-29.

Jang, S.C. (2004). The past, present, and future research of online information search. Journal of Travel \& Tourism Marketing, 17(2/3), $41-47$.

Jeng, J., \& Fesenmaier, D.R. (2002). Conceptualization of the travel planning hierarchy: A review of recent developments. Tourism Analysis, 7(1), 15 - 32.

Jun, S.H., Vogt, C., \& MacKay, K.J. (2007). Relationships between travel information search and travel product purchase in pretrip contexts. Journal of Travel Research 45, 266-274.

Kah, J.A., Vogt, C., \& MacKay, K. (2008). Online travel information search and purchasing by internet use experiences. Information Technology and Tourism, 10(3), 227-243.

Kim, W.G., \& Kim, D.J. (2004). Factors affecting online hotel reservation intention between online and non-online customers. International Journal of Hospitality Management, 23, 381-395.

Kim, J., Bojanic, D.C., \& Warnick, R.B. (2009). Price bundling and travel product pricing practices used by online channels of distribution. Journal of Travel Research, 47(4), 403412.

Kumar, N., Lang, K.R., \& Peng, Q. (2004). Consumer search behavior in online shopping environments. E-Service Journal, 3(3), 87-102.

Lang, T.C. (2000). The effect of the internet on travel consumer purchasing behaviour and implications for travel agencies. Journal of vacation Marketing, 6(4), 368-385.

Law, R., \& Leung, R. (2000). A study of airlines' online reservation services on the internet. Journal of Travel Research, 39, 202-211.

Lee, G-G., \& Lin, H-F. (2005). Customer perceptions of e-service quality in online shopping. International Journal of Retail \& Distribution Management, 33(2), 161-176.

Lee, H., Qu, H., \& Kim, Y. (2007). A study of the impact of personal innovativeness on online travel shopping behavior - A study of Korean travelers. Tourism Management, 28(3), 886-897.

Lessler, J.T. and Kalsbeek, W.D. (1992), Nonsampling Error in Surveys, John Wiley and Sons, New York.

Mast, E.A., Shim, S., \& Morgan, G.A. (1991). In-home videotex shopping: Potential adopters and non-adopters. Journal of Consumer Studies and Home Economics, 15, 133-146.

McIver, J., \& Carmines, E. (1981). Unidimensional Scaling. Sage University Paper Series on Quantitative Applications in the Social Sciences, Series no. 07-024. Beverly Hills and London: Sage Publications. 
Menzel, H. (1953). A new coefficient for scalogram analysis. Public Opinion Quarterly, 17, 268280.

Mills, J., \& Law, R. (2004). Handbook of consumer behaviour, tourism and the Internet. Harworth Hospitality Press, New York.

Mitchell, V-W. (1999). Consumer perceived risk: Conceptualizations and models. European Journal of Marketing, 33(1/2), 163-195.

Money, R.B., \& Crotts, J.C. (2003). The effect of uncertainty avoidance on information search, planning, and purchases of international travel vacations. Tourism Management, 24(2), 191-202.

Monsuwe, T.P., Dellarert, B.G.C., \& De Ruyter, K. (2004). What drives consumers to shop online? A literature review. International Journal of Service Management, 15(1), 102121.

Morrison, A.M., Jing, A., O’Leary, J.T., \& Cai, L. (2001). Predicting usage of the internet for travel bookings: An exploratory study. Information Technology and Tourism, 4(1), 15-30.

Naylor, G., \& Frank, K.E. (2001). The effect of price bundling on consumer perceptions of value. Journal of Services Marketing, 15(4), 270-281.

Nysveen, H. (2003). The importance of risk-reducing value-added services in online environments: An exploratory study on various segments of leisure tourism. Information Technology and Tourism, 6, 113-127.

O'Connor, P. (1999). Electronic Information Distribution in Tourism and Hospitality. CAB, Wallingford.

Pan, B., \& Fesenmaier, D.R. (2006). Online information search: Vacation planning process. Annals of Tourism Research, 33(3), 809-832.

Park, C-H., \& Kim, Y-G. (2003). Identifying key factors affecting consumer purchase behavior in an online shopping context. International Journal of Retail and Distribution Management, 31(1), 16-29.

Park, S. \& Fesenmaier, D.R. (in-press). Nonresponse bias in Internet-based advertising conversion studies. International Journal of Culture, Tourism and Hospitality, forthcoming.

Pennington-Gray, L., \&Vogt, C. (2003). Examining welcome center visitors' travel and information behaviors: Does location of centers or residency matter? Journal of Travel Research, 41(3), 272-280.

Pew Foundation Internet Project (2009). Online activities -total in trend data.

Retrieved December 20, 2010, from http://www.pewinternet.org/Static-Pages/TrendData/Online-Activites-Total.aspx.

Roehl, W.S. (1990). Travel agent attitudes toward China after Tiananmen Square. Journal of 
Travel Research, 29(2), 16-22.

Sheldon, P. J., \& Mak, J. (1987). The demand for package tours: A mode choice model. Journal of Travel Research, 25(3), 13-17.

Stouffer, S., Guttman, L., Suchman, E., Lazarsfeld, P., Star, S., \& Clausen, J. (1950). Measurement and prediction. Princeton University Press, Princeton, N.J.

Susskind, A.M., Bonn, M.A., \& Dev, C.S. (2003). To look or book: An examination of consumers' apprehensiveness toward internet use. Journal of Travel Research, 41(3), 256-264.

Tanford, S. Baloglu, S., \& Erdem, M. (2011). Travel packaging on the Internet: The impact of pricing information and perceived value on consumer choice. Journal of Travel Research.1-13.

USTA (2009). Travelers' Use of the Internet. U. S. Travel Association.

Retrieved December 09, 2010, from http://www.ustravel.org/

Wen, I. (2009). Factors affecting the online travel buying decision: A review. International Journal of Contemporary Hospitality Management, 21(6), 752-765.

Werthner, H., \& Klein, S. (1999). Information technology and tourism-a challenging relationship. Springer, New York.

Xiang, Z., Wöber, K., \& Fesenmaier, D.R. (2008). Representation of the online tourism domain in search engines. Journal of Travel Research, 47(2), 137-150.

Yang, B., \& Lester, D. (2004). Attitudes toward buying online. Cyberpsychology and Behavior, $7(1), 85-92$.

Zhou, L., Dai, L., \& Zhang, D. (2007). Online shopping acceptance model: A critical survey of consumer factors in online shopping. Journal of Electronic Commerce Research, 8(1), 41-62. 
Figure 1.

Online Travel Product Purchase Behavior

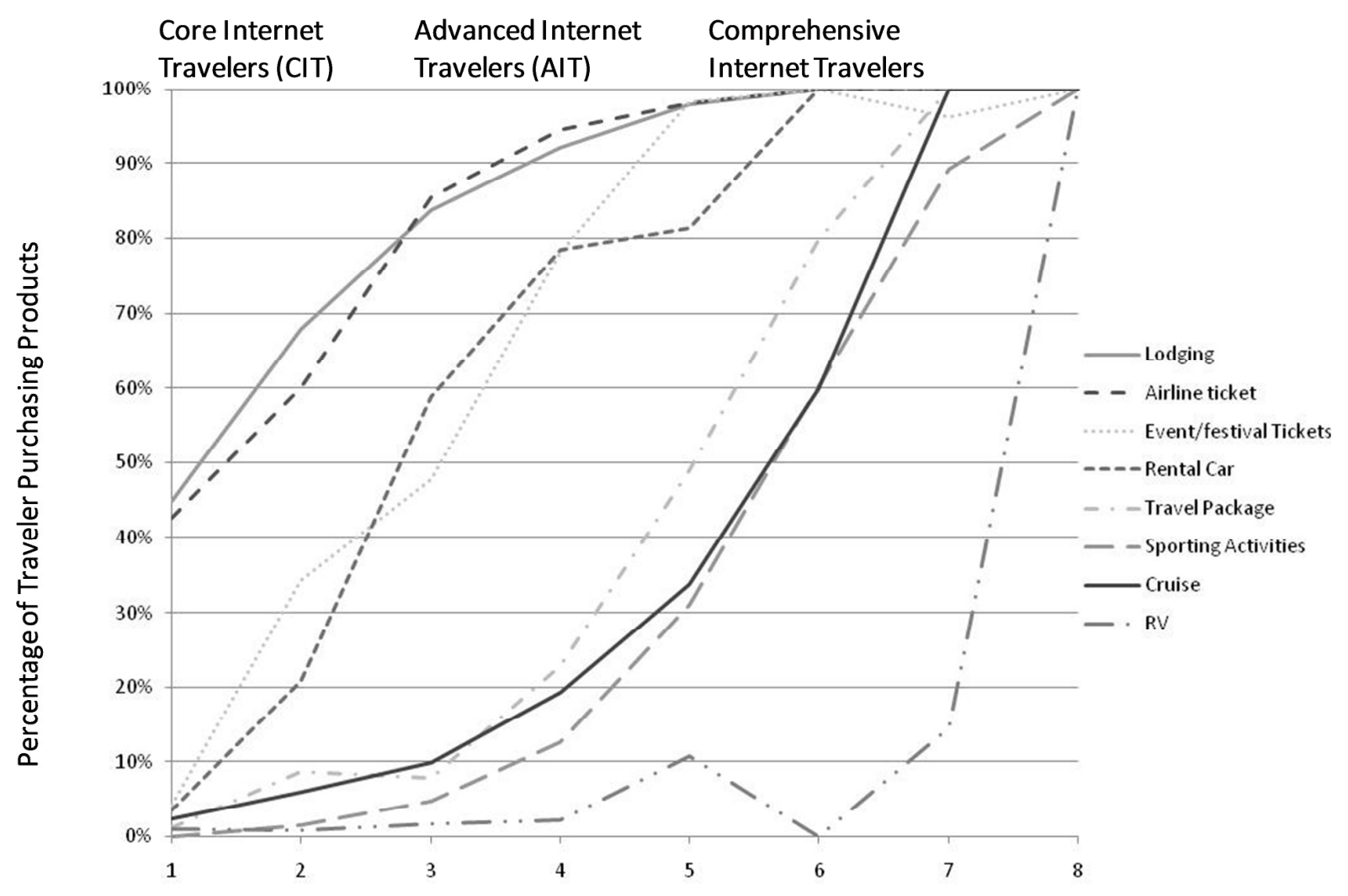


Table 1

Profile of Online American Travelers

\begin{tabular}{|c|c|c|c|}
\hline \multirow[t]{2}{*}{ Variable } & \multicolumn{3}{|c|}{ Frequency $(\%)$} \\
\hline & $\begin{array}{c}\text { American Online } \\
\text { Travelers } \\
(\mathbf{N}=\mathbf{2 , 1 3 7})\end{array}$ & $\begin{array}{c}\text { Online Travelers } \\
\text { purchasing } \\
\text { products } \\
(\mathbf{N}=\mathbf{1 , 6 1 0})\end{array}$ & $\begin{array}{l}\text { Online Travelers } \\
\text { who did not } \\
\text { purchase products } \\
(\mathbf{N}=\mathbf{5 2 7}) \\
\end{array}$ \\
\hline \multicolumn{4}{|l|}{ Gender: } \\
\hline Female & $1,064(51.4)$ & $817(51.4)^{\mathrm{b}}$ & $246(51.3)^{\mathrm{b}}$ \\
\hline Male & $1,005(48.6)$ & 771 (48.6) & $234(48.8)$ \\
\hline \multicolumn{4}{|l|}{ Age: } \\
\hline $18-21$ years & $192(9.0)$ & $151(9.4)^{\mathrm{b}}$ & $41(7.8)^{\mathrm{b}}$ \\
\hline $22-29$ years & $320(15.0)$ & $252(15.7)$ & $68(12.9)$ \\
\hline $30-39$ years & $452(21.2)$ & $342(21.3)$ & $110(20.8)$ \\
\hline $40-49$ years & 419 (19.6) & $333(20.7)$ & $86(16.3)$ \\
\hline $50-59$ years & $299(14.0)$ & 208 (12.9) & $92(17.4)$ \\
\hline $60-69$ years & $200(9.4)$ & $144(8.9)$ & $55(10.4)$ \\
\hline 70 and above & $255(11.9)$ & $179(11.1)$ & $76(14.4)$ \\
\hline \multicolumn{4}{|l|}{ Annual household income: } \\
\hline Less than $\$ 20,000$ & $158(7.7)$ & $84(5.3)^{\mathrm{b}}$ & $74(15.4)^{\mathrm{b}}$ \\
\hline$\$ 20,000-\$ 29,999$ & $185(9.0)$ & $131(8.3)$ & $54(11.3)$ \\
\hline$\$ 30,000-\$ 39,999$ & $228(11.0)$ & $157(9.9)$ & $71(14.8)$ \\
\hline$\$ 40,000-\$ 49,999$ & $206(10.0)$ & $156(9.8)$ & $49(10.2)$ \\
\hline$\$ 50,000-\$ 74,999$ & $483(23.4)$ & $372(23.5)$ & $112(23.4)$ \\
\hline$\$ 75,000-\$ 99,999$ & $350(17.0)$ & $289(18.2)$ & $60(12.5)$ \\
\hline$\$ 100,000-\$ 149,999$ & 239 (11.6) & $219(13.8)$ & $21(4.4)$ \\
\hline$\$ 150,000-\$ 199,999$ & $62(3.0)$ & $56(3.5)$ & $6(1.3)$ \\
\hline$\$ 200,000$ or more & $39(1.9)$ & $37(2.3)$ & $2(.4)$ \\
\hline Do not wish to comment & $114(5.5)$ & $85(5.4)$ & $30(6.3)$ \\
\hline \multicolumn{4}{|l|}{ Highest education level: } \\
\hline Less than high school & $26(1.3)$ & $13(.8)^{\mathrm{b}}$ & $13(2.7)^{\mathrm{b}}$ \\
\hline Completed high school & $302(14.6)$ & $214(13.5)$ & $88(18.3)$ \\
\hline Some college, not completed & $693(33.5)$ & $525(33.1)$ & $169(35.1)$ \\
\hline Completed college & $593(28.7)$ & $445(28.0)$ & $148(30.8)$ \\
\hline $\begin{array}{l}\text { Post graduate work } \\
\text { started or completed }\end{array}$ & 443 (21.4) & $384(24.2)$ & $59(12.3)$ \\
\hline Do not wish to comment & $11(.5)$ & $7(.4)$ & $4(.8)$ \\
\hline \multicolumn{4}{|l|}{ Marital status: } \\
\hline Married & $1,208(58.4)$ & $962(60.5)^{\mathrm{b}}$ & $246(51.1)^{\mathrm{b}}$ \\
\hline Single or never married & 343 (16.6) & $235(14.8)$ & 109 (22.7) \\
\hline Divorced, separated, widowed & $368(17.8)$ & $276(17.4)$ & $92(19.1)$ \\
\hline Living with partner & $144(7.0)$ & $112(7.0)$ & $32(6.7)$ \\
\hline Do not wish to comment & $5(.2)$ & $4(.3)$ & $2(.4)$ \\
\hline \multicolumn{4}{|l|}{ Current employment } \\
\hline Employed full-time & $886(42.8)$ & $707(44.5)^{\mathrm{b}}$ & $179(37.3)^{\mathrm{b}}$ \\
\hline
\end{tabular}


Employed part-time Retired

Not employed

Do not wish to comment
$275(13.3)$

$498(24.1)$

$360(17.4)$

$50(2.4)$
$213(13.4)$

394 (24.8)

$242(15.2)$

$32(2.0)$
$62(12.9)$

$104(21.7)$

$117(24.4)$

$18(3.8)$

Note: $\mathrm{b}$ refers to statistically significant difference $(\alpha=.05)$ using Chi-square pairwise comparison analysis 
Table 2

Purchase of Online Travel Products by Online American Travelers

\begin{tabular}{lcc}
\hline Online Travel Products & Frequency & Percent \\
\hline Lodging accommodations & 1,111 & $67.4 \%$ \\
Airline tickets & 1,074 & $65.1 \%$ \\
Tickets to attractions/events & 601 & $37.3 \%$ \\
Car rental & 563 & $34.9 \%$ \\
Travel package & 184 & $11.4 \%$ \\
Cruise reservations & 162 & $10.1 \%$ \\
Sport activity reservations & 97 & $6.1 \%$ \\
RV rental/purchase & 32 & $2.0 \%$ \\
\hline
\end{tabular}


Table 3

Number of Online Travel Products Purchased

\begin{tabular}{lcc}
\hline $\begin{array}{l}\text { Number of } \\
\text { Travel Products }\end{array}$ & Frequency & Percent \\
\hline 1 & 516 & $32.1 \%$ \\
2 & 443 & $27.5 \%$ \\
3 & 343 & $21.3 \%$ \\
4 & 196 & $12.2 \%$ \\
5 & 79 & $4.8 \%$ \\
6 & 20 & $1.2 \%$ \\
7 & 11 & $0.7 \%$ \\
8 & 3 & $0.2 \%$ \\
\hline
\end{tabular}




\section{Table 4}

Scalability Matrix of Online Travel Product Purchases ${ }^{\text {a }}$

\begin{tabular}{|c|c|c|c|c|c|c|c|c|c|c|}
\hline & \multicolumn{9}{|c|}{ Number of Travel Products Purchased } & \multirow{2}{*}{$\begin{array}{c}\text { Cumulative } \\
\%^{\mathrm{b}}\end{array}$} \\
\hline & 0 & 1 & 2 & 3 & 4 & 5 & 6 & 7 & 8 & \\
\hline Lodging accommodations & $0 \%$ & $45 \%$ & $68 \%$ & $84 \%$ & $92 \%$ & $98 \%$ & $100 \%$ & $100 \%$ & $100 \%$ & $687 \%$ \\
\hline Airline tickets & $0 \%$ & $43 \%$ & $60 \%$ & $85 \%$ & $94 \%$ & $98 \%$ & $100 \%$ & $100 \%$ & $100 \%$ & $681 \%$ \\
\hline Tickets to attractions/events & $0 \%$ & $4 \%$ & $34 \%$ & $48 \%$ & $78 \%$ & $98 \%$ & $100 \%$ & $96 \%$ & $100 \%$ & $559 \%$ \\
\hline Car rental & $0 \%$ & $4 \%$ & $21 \%$ & $59 \%$ & $78 \%$ & $81 \%$ & $100 \%$ & $100 \%$ & $100 \%$ & $543 \%$ \\
\hline Travel package & $0 \%$ & $1 \%$ & $9 \%$ & $8 \%$ & $23 \%$ & $49 \%$ & $80 \%$ & $100 \%$ & $100 \%$ & $369 \%$ \\
\hline Cruise reservations & $0 \%$ & $2 \%$ & $6 \%$ & $10 \%$ & $19 \%$ & $34 \%$ & $60 \%$ & $100 \%$ & $100 \%$ & $331 \%$ \\
\hline Sport activity reservations & $0 \%$ & $0 \%$ & $2 \%$ & $5 \%$ & $13 \%$ & $31 \%$ & $60 \%$ & $89 \%$ & $100 \%$ & $300 \%$ \\
\hline RV rental/purchase & $0 \%$ & $1 \%$ & $1 \%$ & $2 \%$ & $2 \%$ & $11 \%$ & $0 \%$ & $14 \%$ & $100 \%$ & $131 \%$ \\
\hline Number of responses & 527 & 516 & 443 & 343 & 196 & 78 & 20 & 11 & 3 & $1610^{\mathrm{c}}$ \\
\hline
\end{tabular}

${ }^{\mathrm{a} C o e f f i c i e n t}$ of reproducibility $(\mathrm{CR})=0.88$. Minimum marginal reproducibility $(\mathrm{MMR})=0.67$. Percent improvement $=0.21$.

Coefficient of Scaleability $(\mathrm{CS})=0.66$

${ }^{b}$ refers to the percentage of online travelers excluding ' 0 ' column in number of products purchased.

${ }^{c}$ refers to the number of respondents excluding ' 0 ' column in number of products purchased. 
Table 5

Demographic Differences between Travel Product Groups

\begin{tabular}{|c|c|c|c|c|}
\hline Variables & $\begin{array}{c}\text { Core } \\
\text { Internet } \\
\text { Traveler } \\
(\mathbf{n}=960) \\
\end{array}$ & $\begin{array}{l}\text { Advanced } \\
\text { Internet } \\
\text { Traveler } \\
(\mathbf{n}=539) \\
\end{array}$ & $\begin{array}{c}\text { Comprehensive } \\
\text { Internet } \\
\text { Travelers } \\
(\mathbf{n}=111) \\
\end{array}$ & $\begin{array}{l}\text { Chi- } \\
\text { Square }^{1}\end{array}$ \\
\hline Age: & & & & 12.65 \\
\hline $18-21$ & $9.1 \%^{\mathrm{b}}$ & $9.1 \%$ & $13.5 \%^{\mathrm{b}}$ & \\
\hline $22-29$ & $15.9 \%$ & $15.1 \%$ & $16.2 \%$ & \\
\hline $30-39$ & $20.3 \%$ & $22.3 \%$ & $24.3 \%$ & \\
\hline $40-49$ & $22.2 \%$ & $20.1 \%$ & $10.8 \%$ & \\
\hline $50-59$ & $13.2 \%$ & $12.1 \%$ & $14.4 \%$ & \\
\hline $60-69$ & $9.1 \%$ & $9.3 \%$ & $7.2 \%$ & \\
\hline 70 and above & $10.2 \%$ & $12.1 \%$ & $13.5 \%$ & \\
\hline Annual income: & & & & 148.72 \\
\hline Less than $\$ 20,000$ & $7.1 \%{ }^{\mathrm{ab}}$ & $2.8 \%^{\mathrm{ac}}$ & $2.7 \%^{\mathrm{bc}}$ & $* * *$ \\
\hline$\$ 20,000-\$ 29,999$ & $11.1 \%$ & $3.2 \%$ & $9.0 \%$ & \\
\hline$\$ 30,000-\$ 39,999$ & $12.8 \%$ & $6.7 \%$ & $0.9 \%$ & \\
\hline$\$ 40,000-\$ 49,999$ & $10.8 \%$ & $8.2 \%$ & $9.0 \%$ & \\
\hline$\$ 50,000-\$ 74,999$ & $23.6 \%$ & $23.6 \%$ & $21.6 \%$ & \\
\hline$\$ 75,000-\$ 99,999$ & $16.8 \%$ & $21.3 \%$ & $16.2 \%$ & \\
\hline$\$ 100,000-\$ 149,999$ & $9.5 \%$ & $17.8 \%$ & $31.5 \%$ & \\
\hline$\$ 150,000-\$ 199,999$ & $1.7 \%$ & $6.4 \%$ & $4.5 \%$ & \\
\hline$\$ 200,000$ or more & $1.3 \%$ & $4.1 \%$ & $2.7 \%$ & \\
\hline Do not wish to comment & $5.4 \%$ & $5.8 \%$ & $1.8 \%$ & \\
\hline Education: & & & & 62.53 \\
\hline Less than high school & $1.0 \%^{\mathrm{ab}}$ & $0.6 \%^{\mathrm{a}}$ & $1.8 \%^{\mathrm{b}}$ & $* * *$ \\
\hline Completed high school & $16.6 \%$ & $9.0 \%$ & $7.3 \%$ & \\
\hline $\begin{array}{l}\text { Some college, not } \\
\text { completed }\end{array}$ & $36.8 \%$ & $28.0 \%$ & $25.5 \%$ & \\
\hline Completed college & $25.4 \%$ & $31.0 \%$ & $35.5 \%$ & \\
\hline $\begin{array}{l}\text { Post graduate work started } \\
\text { or completed }\end{array}$ & $19.5 \%$ & $31.4 \%$ & $30.0 \%$ & \\
\hline Current Employment: & & & & 23.88 \\
\hline Employed full-time & $40.4 \%^{\mathrm{ab}}$ & $49.6 \%^{\mathrm{a}}$ & $55.5 \%{ }^{\mathrm{b}}$ & $* * *$ \\
\hline Employed part-time & $13.7 \%$ & $12.7 \%$ & $14.5 \%$ & \\
\hline Retired & $26.6 \%$ & $22.5 \%$ & $20.0 \%$ & \\
\hline Not employed & $16.5 \%$ & $14.0 \%$ & $10.0 \%$ & \\
\hline
\end{tabular}

Note: statistically significant difference $(\alpha=.05)$ using Chi-square pairwise comparison analysis; $\mathrm{a}=\mathrm{a}$ comparison between Core Internet Travelers and Advanced Internet Travelers; $b=a$ comparison between Core Internet Travelers and Comprehensive Internet Travelers; c = a comparison between Advanced Internet Travelers and Comprehensive Internet Travelers. 1 refers to Chi-square multiple comparison analysis 
Table 6

Travel Planning Differences between Travel Product Groups

\begin{tabular}{|c|c|c|c|c|}
\hline Variables & $\begin{array}{c}\text { Core } \\
\text { Internet } \\
\text { Traveler } \\
(\mathbf{n}=960) \\
\end{array}$ & $\begin{array}{c}\text { Advanced } \\
\text { Internet } \\
\text { Traveler } \\
(\mathbf{n}=\mathbf{5 3 9}) \\
\end{array}$ & $\begin{array}{c}\text { Comprehensive } \\
\text { Internet } \\
\text { Travelers } \\
(\mathbf{n}=\mathbf{1 1 1}) \\
\end{array}$ & $\begin{array}{c}\text { Chi- } \\
\text { square }\end{array}$ \\
\hline $\begin{array}{l}\text { Number of pleasure trips in the } \\
\text { past } 12 \text { months }\end{array}$ & & & & $79.42 * * *$ \\
\hline One trip & $24.9 \%^{\mathrm{ab}}$ & $13.3 \%^{\mathrm{ac}}$ & $4.7 \%^{\mathrm{bc}}$ & \\
\hline 2 trips & $28.4 \%$ & $24.6 \%$ & $18.9 \%$ & \\
\hline 3-4 trips & $29.6 \%$ & $36.9 \%$ & $34.0 \%$ & \\
\hline 5 or more trips & $17.0 \%$ & $25.2 \%$ & $42.5 \%$ & \\
\hline $\begin{array}{l}\text { The proportion of using the Internet } \\
\text { for travel planning }\end{array}$ & & & & $50.52 * * *$ \\
\hline All or $100 \%$ & $28.5 \%^{\mathrm{ab}}$ & $35.4 \%^{\mathrm{a}}$ & $33.0 \%{ }^{\mathrm{b}}$ & \\
\hline $75-99 \%$ & $29.6 \%$ & $32.1 \%$ & $42.9 \%$ & \\
\hline $50-74 \%$ & $19.7 \%$ & $21.3 \%$ & $17.0 \%$ & \\
\hline $25-49 \%$ & $13.9 \%$ & $8.5 \%$ & $7.1 \%$ & \\
\hline $1-24 \%$ & $7.3 \%$ & $2.6 \%$ & $0.0 \%$ & \\
\hline Uncertain & $0.3 \%$ & $0.0 \%$ & $0.0 \%$ & \\
\hline $\begin{array}{l}\text { The proportion of using the Interne } \\
\text { for travel product purchasing }\end{array}$ & & & & $53.48 * * *$ \\
\hline All or $100 \%$ & $35.3 \%{ }^{\mathrm{ab}}$ & $38.6 \%^{\mathrm{a}}$ & $35.1 \%^{\mathrm{b}}$ & \\
\hline $75-99 \%$ & $26.4 \%$ & $34.4 \%$ & $42.3 \%$ & \\
\hline $50-74 \%$ & $17.1 \%$ & $17.6 \%$ & $15.3 \%$ & \\
\hline $25-49 \%$ & $11.9 \%$ & $6.7 \%$ & $5.4 \%$ & \\
\hline $1-24 \%$ & $7.7 \%$ & $2.7 \%$ & $1.8 \%$ & \\
\hline I do not know & $1.2 \%$ & $0.0 \%$ & $0.0 \%$ & \\
\hline
\end{tabular}

Note: statistically significant difference $(\alpha=.05)$ using Chi-square pairwise comparison analysis; a $=$ a comparison between Core Internet Travelers and Advanced Internet Travelers; $b=a$ comparison between Core Internet Travelers and Comprehensive Internet Travelers; $\mathrm{c}=\mathrm{a}$ comparison between Advanced Internet Travelers and Comprehensive Internet Travelers. 1 refers to Chi-square multiple comparison analysis 
Table 7

Information Search Differences between Travel Product Groups

\begin{tabular}{lccc}
\hline Types of online sources & $\begin{array}{c}\text { Core } \\
\text { Internet } \\
\text { Traveler } \\
(\mathbf{n = 9 6 0})\end{array}$ & $\begin{array}{c}\text { Advanced } \\
\text { Internet } \\
\text { Traveler } \\
(\mathbf{n}=539)\end{array}$ & $\begin{array}{c}\text { Comprehensive } \\
\text { Internet } \\
\text { Travelers } \\
(\mathbf{n}=111)\end{array}$ \\
\hline Online travel agency & $60.4 \%^{\mathrm{ab}}$ & $75.1 \%^{\mathrm{ac}}$ & $81.1 \%^{\mathrm{bc}}$ \\
Company sites & $51.9 \%^{\mathrm{ab}}$ & $74.2 \%^{\mathrm{ac}}$ & $83.8 \%^{\mathrm{bc}}$ \\
Search engines & $49.6 \%^{\mathrm{ab}}$ & $55.5 \%^{\mathrm{ac}}$ & $76.6 \%^{\mathrm{bc}}$ \\
Destination sites & $33.3 \%^{\mathrm{ab}}$ & $43.2 \%^{\mathrm{ac}}$ & $57.7 \%^{\mathrm{bc}}$ \\
General travel sites & $9.7 \%^{\mathrm{ab}}$ & $14.5 \%^{\mathrm{ac}}$ & $38.7 \%^{\mathrm{bc}}$ \\
Travel guide book sites & $5.9 \%^{\mathrm{ab}}$ & $13.5 \%^{\mathrm{ac}}$ & $36.6 \%^{\mathrm{bc}}$ \\
Newspaper or magazine & $3.2 \%^{\mathrm{ab}}$ & $7.6 \%^{\mathrm{ac}}$ & $26.8 \%^{\mathrm{bc}}$ \\
Community sites & $2.0 \%^{\mathrm{ab}}$ & $3.2 \%^{\mathrm{ac}}$ & $12.6 \%^{\mathrm{bc}}$ \\
Consumer generated content sites & $2.1 \%^{\mathrm{b}}$ & $1.5 \%^{\mathrm{c}}$ & $23.2 \%$ \\
Social networking sites & $3.1 \%^{\mathrm{b}}$ & $3.9 \%^{\mathrm{c}}$ & $17.1 \%^{\mathrm{bc}}$ \\
Special interest & $7.5 \%^{\mathrm{b}}$ & $7.4 \%^{\mathrm{c}}$ & $21.6 \%^{\mathrm{bc}}$ \\
\hline
\end{tabular}

Note: statistically significant difference $(\alpha=.05)$ using Chi-square pairwise comparison analysis; a = a comparison between Core Internet Travelers and Advanced Internet Travelers; $\mathrm{b}=\mathrm{a}$

comparison between Core Internet Travelers and Comprehensive Internet Travelers; $\mathrm{c}=\mathrm{a}$ comparison between Advanced Internet Travelers and Comprehensive Internet Travelers. 1 refers to Chi-square multiple comparison analysis 
Table 8

Internet Behavior Differences between Travel Product Groups

\begin{tabular}{|c|c|c|c|c|}
\hline Variables & $\begin{array}{c}\text { Core } \\
\text { Internet } \\
\text { Traveler } \\
(\mathbf{n}=960)\end{array}$ & $\begin{array}{l}\text { Advanced } \\
\text { Internet } \\
\text { Traveler } \\
(n=539)\end{array}$ & $\begin{array}{c}\text { Comprehensive } \\
\text { Internet } \\
\text { Travelers } \\
(\mathbf{n}=111)\end{array}$ & $F$ value \\
\hline \multicolumn{5}{|l|}{ Internet skill/knowledge } \\
\hline I am very skilled at using the Internet & $3.73^{\mathrm{ab}}$ & $4.04^{\mathrm{ac}}$ & $4.11^{\mathrm{bc}}$ & $16.04 * *$ \\
\hline $\begin{array}{l}\text { I know how to find what I want on the } \\
\text { Internet }\end{array}$ & $4.09^{\mathrm{ab}}$ & 4.32 & $4.26^{\mathrm{c}}$ & $8.60 * * *$ \\
\hline \multicolumn{5}{|l|}{ Perceived technology innovativeness } \\
\hline $\begin{array}{l}\text { I know about new technologies before } \\
\text { most other people in my social circle do }\end{array}$ & $2.70^{\mathrm{ab}}$ & $3.01^{\mathrm{ac}}$ & $3.41^{\mathrm{bc}}$ & $23.68 * * *$ \\
\hline $\begin{array}{l}\text { I am among the first in my circle of } \\
\text { friends to buy a new technology }\end{array}$ & $2.44^{\mathrm{ab}}$ & $2.70^{\mathrm{ac}}$ & $3.40^{\mathrm{bc}}$ & $32.49 * * *$ \\
\hline $\begin{array}{l}\text { Compared to my friends, I use new } \\
\text { technologies a lot }\end{array}$ & $2.83^{\mathrm{ab}}$ & $3.12^{\mathrm{ac}}$ & $3.63^{\mathrm{bc}}$ & $25.00 * * *$ \\
\hline Internet satisfaction & $4.50^{\mathrm{ab}}$ & $4.67^{\mathrm{a}}$ & $4.61^{\mathrm{c}}$ & $12.89 * * *$ \\
\hline $\begin{array}{l}\text { Intention to use the Internet for travel } \\
\text { planning }\end{array}$ & $5.45^{\mathrm{ab}}$ & $5.74^{\mathrm{a}}$ & $5.62^{\mathrm{c}}$ & $27.95^{* * *}$ \\
\hline
\end{tabular}

Note: ANOVA was used to compare the mean differences; $* * p$ value $<.01 ; * * * p$ value $<.001$

Tukey's post-hoc analysis was used to compare mean differences between three groups; $a=a$ comparison between Core Internet Travelers and Advanced Internet Travelers; $b=a$ comparison between Core Internet Travelers and Comprehensive Internet Travelers; c = a comparison between Advanced Internet Travelers and Comprehensive Internet Travelers. 